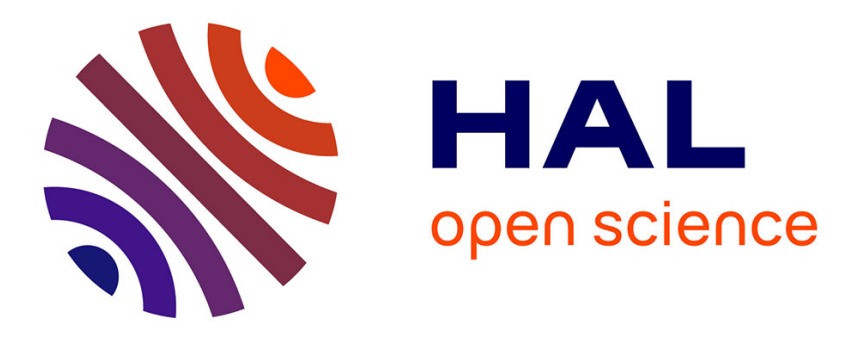

\title{
R-spondin1 is required to normal epithelial morphogenesis during mammary gland development
}

Sead Chadi, Laurine Buscara, Christine Péchoux, Jose Costa, Johann Laubier,

Marie-Christine Chaboissier, Eric Pailhoux, Jean-Luc Vilotte, Eric Chanat, Fabienne Le Provost

\section{To cite this version:}

Sead Chadi, Laurine Buscara, Christine Péchoux, Jose Costa, Johann Laubier, et al.. R-spondin1 is required to normal epithelial morphogenesis during mammary gland development. Mammary Gland Biology Gordon Conference, Jun 2009, Salve Regina, United States. hal-01193690

\section{HAL Id: hal-01193690 \\ https://hal.science/hal-01193690}

Submitted on 6 Jun 2020

HAL is a multi-disciplinary open access archive for the deposit and dissemination of scientific research documents, whether they are published or not. The documents may come from teaching and research institutions in France or abroad, or from public or private research centers.
L'archive ouverte pluridisciplinaire HAL, est destinée au dépôt et à la diffusion de documents scientifiques de niveau recherche, publiés ou non, émanant des établissements d'enseignement et de recherche français ou étrangers, des laboratoires publics ou privés. 


\section{R-spondin1 is required for normal epithelial morphogenesis during mammary gland development.}

Sead CHADI a1, Laurine BUSCARA ${ }^{a 1}$, Christine PECHOUX ${ }^{b}$, José COSTA ${ }^{a}$, Johann LAUBIER ${ }^{a}$, Marie-Christine CHABOISSIER ${ }^{c}$, Eric PAILHOUX' ${ }^{\mathrm{d}}$, Jean-Luc VILOTTE ${ }^{\mathrm{a}}$, Eric CHANAT ${ }^{\mathrm{b}}$, Fabienne LE PROVOST ${ }^{\mathrm{a}}$

aINRA, UMR1313 Génétique Animale et Biologie Intégrative, F-78 350 Jouy-en-Josas, France ; bINRA, UR1196 Génomique et Physiologie de la Lactation, F-78 350 Jouyen-Josas, France ; 'INSERM, U636 Génétique du Développement Normal et Pathologique, F-06 108 Nice, France ; 'dNRA, UMR1198 Biologie du Développement et de la Reproduction, F-78 350 Jo

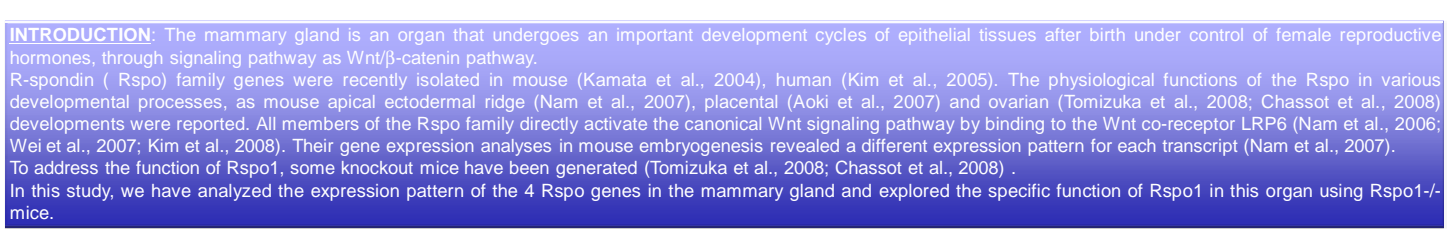

\section{RESULTS:}

1/ Expression profiles of Rspo genes in mouse mammary gland.

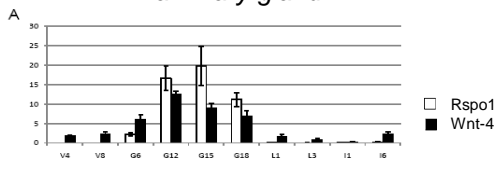

B

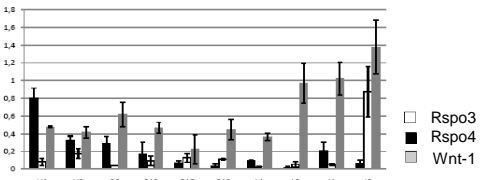

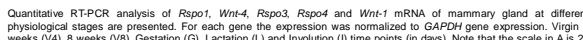

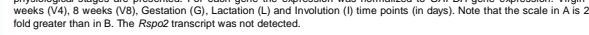

The expression levels and patterns of the 4 members of Rspo family are different during the development and differentiation of the mouse mammary gland, suggesting that they have difieren
roles. Aspot gene, which is the most expressed, has an expression pattern similar to that of the
Wnt-4gene

3/ Localization of Rspo1 in mammary epithelial cells.
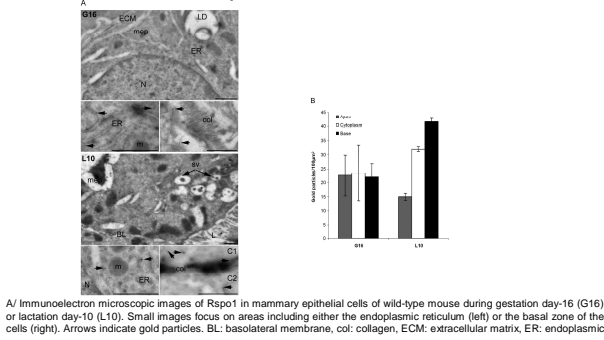

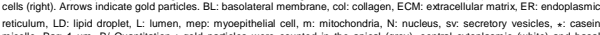

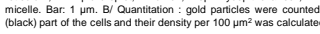

At gestation day-16, Rspo 1 labelling was found over the cytoplasm and the endoplasmic reticulum, as

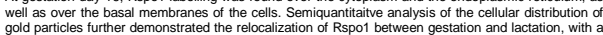

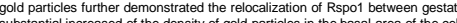

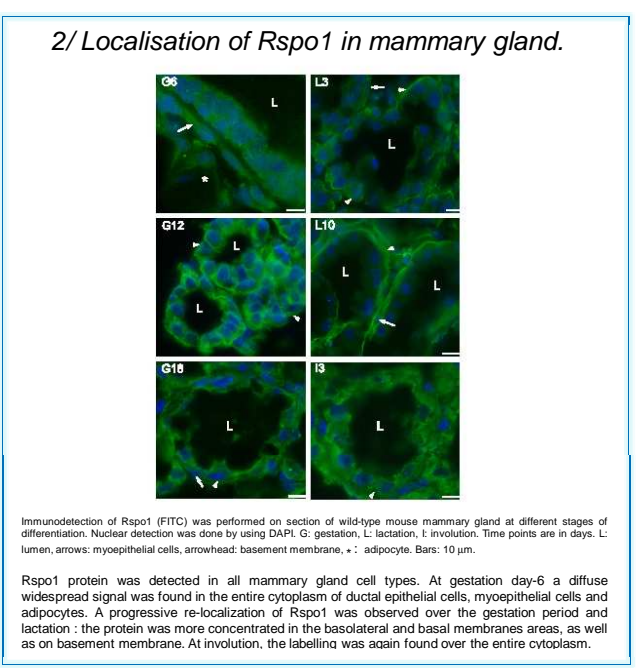

4/ Mammary gland development during gestation is affected in Rspo1 -/- mice.
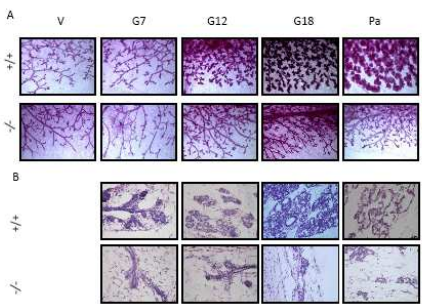

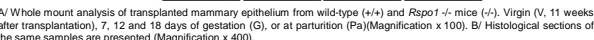
To address the function of Rspot during the normal mouse mammary gland development, we performed Rspo1 \%- mammary gland epithelium transplantations in "cleared" fat pad nude mice. A defect of sidebranching tormation is observed in virgin animal and during gestation. This branchin phenotype became as
gestation and parturition

CONCLUSIONS: The expression levels and patterns of the 4 Rspo genes are different during the development and differentiation of the mouse mammary gland, suggesting that they have different roles in its biology.

列 formation. The comparison with Wnt-4 knockout effect suggest that Rspo1 could be activated upstream of Wnt-4 and may turn on Wnt-4 alongside other signaling pathways. 